\title{
Effect of Crocus sativus and its active compounds for the treatment of several diseases: A review
}

\author{
Rafie Hamidpour, Soheila Hamidpour, Mohsen Hamidpour, Mina Shahlari
}

\begin{abstract}
The purpose of this article is to use literature search engines such as PubMed and SciFinder to locate scholarly journal articles pertaining saffron, its preparation, analysis, and its use in cancer treatments. Saffron comes from the dried red stigmas of the Crocus sativus L. flower. Along with its use in cooking and in traditional medicine, it has numerous applications as an antitoxic, anti-oxidant, and anti-cancer agent, due to its secondary metabolites and their derivatives are safranal, crocins, crocetin and dymethyl-crocetin. This study demonstrate that Crocus sativus extract (CSE) and its major constituents, crocin, and crocetin, significantly inhibited the growth of certain cancer cells while not effecting normal cells. Crocus sativus $L$. extract should be investigated further as a viable agent in the treatment of prostate, pancreatic or other types of cancer.
\end{abstract}

Keywords: Crocus sativus L., Tumor inhibitor, Saffron components, Nutritional supplements

$* * * * * * * * *$

Rafie Hamidpour ${ }^{1}$, Soheila Hamidpour ${ }^{2}$, Mohsen Hamidpour ${ }^{3}$, Mina Shahlari ${ }^{4}$

Affiliations: ${ }^{1} \mathrm{PhD}$, President, Pars Bioscience, Leawood, Kansas, United States; ${ }^{2} \mathrm{MD}$, Pars Bioscience, Leawood, Kansas, United States; ${ }^{3} \mathrm{PhD}$, Pars Bioscience, Leawood, Kansas, United States; ${ }^{4} \mathrm{BA}$, Pars Bioscience, Leawood, Kansas, United States.

Corresponding Author: Rafie Hamidpour, Pars Bioscience LLC, 14109 Cambridge Lane, Leawood, Kansas, United States 66224; Ph: (913) 432-0107; Fax: (913) 432-5708; Email: rafi@parsbioscience.com

Received: 16 November 2012

Accepted: 12 January 2013

Published: 01 December 2013
Hamidpour R, Hamidpour S, Hamidpour M, Shahlari $M$. Effect of Crocus sativus and its active compounds for the treatment of several diseases: A review. International Journal of Case Reports and Images 2013;4(12):666-670.

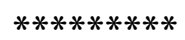

doi:10.5348/ijcri-2013-12-407-RA-1

\section{INTRODUCTION}

Saffron is one of the most expensive spices in the world, derived from the dry stigmata of Crocus sativus L. - a member of the Iridaceae (Iris) family. Saffron is handharvested during the flowering season. This process is very time consuming which involves picking the stigmata by hand and then carefully drying the stigmata to produce a quality product. One stigma of saffron weighs about $2 \mathrm{mg}$ and each flower has three stigmata. In order to obtain $1 \mathrm{~kg}$ of spice 150,000 flowers must be picked [1].

Saffron (Crocus sativus L.) is mostly cultivated in Spain, Iran, India, Greece, China and some other European and Asian countries. The quality and chemical composition of saffron are affected by the region in which saffron is grown, the drying process, the conditions of packaging, storage of saffron and the analytical extraction methods which have been used $[1,2]$.

The nutritional supplement value of saffron (Crocus sativus L.) which was provided by pars bioscience LLC in powder form, to Covance, Madison. WI laboratory was analyzed and shown to include the following contents: NL-Proximate (moisture, ash, protein, fat, total carbohydrates, calories, and calories from fat), results of these analyzes are given in Table 1. Vitamins (vitamin A, vitamin $\mathrm{C}$, and folic acid), and minerals (calcium, copper, iron, magnesium, manganese, phosphorus, potassium, sodium, and zinc) are detailed in Table 2. The results of analysis of saffron fatty acid profile are given in Table 3 .

The analysis of the saffron was conducted by grinding and extracting saffron, and analyzing the extract using 
HPLC/UV-MS analysis to identify the major components of saffron (Figure 1).

To date, the following components have been identified in saffron: safranal which is the principal substance responsible for the aroma of saffron, dimethylcrocetin, crocetin esters (cis-crocetin and trans-crocetin), picrocrocin is the substance responsible for bitter taste of saffron [1], crocin which are the major components responsible for the color of saffron, trans-crocin-2, transcrocin-2', trans-crocin-3, trans crocin-4, cis-crocin-1, cis-crocin-2, cis-crocin-3, cis-crocin-4, cis-crocin-5, anthocyanin, carotene, and lycopene [1-10].

The main uses of saffron are in cooking, food coloring, in perfume and cosmetics [1, 11]. Saffron has also traditionally been regarded as a highly valued medicinal plant to treat wide variety of ailments such as depression, respiratory problems, colds, asthma and heart diseases. [12]. More recently, as the current culture has been changing, more researches have been done analyzing the effects of traditional herbs and spices as treatment for the severe diseases [11].

Several studies have been performed on the use of saffron or its constituents in the treatment of a variety of cancers including colorectal cancer cells (HCT-116, SW-480, and HT-29) [4], breast cancer cells (MCF7 and MDA-MB-231) [7], non-small cell lung cancer (NSCLC) cells [4], lung adenocarcinoma cells (A549), lung fibroblasts cells (WI-38), VA-13 cells (WI-38 cells transformed in vitro by SV4O tumor virus) [12-14], lung cancer-bearing mice [15], skin carcinogenesis in mice[16, 17], leukemia cells (HL-6o) [4,9], osteosarcoma [4,12], fibrosarcoma $[4,12]$, ovarian carcinoma $[4,12]$, and cervical epithelioid carcinoma cells (HeLa) [12, 14, 18]. Saffron significantly inhibited the growth of colorectal cancer cells while not affecting normal cells [4]. Saffron showed a dose-dependent inhibitory response on breast cancer cells [7]. Crocetin inhibited the three malignant human cell lines (HeLa, A549, and VA13) [14]. Overall, saffron inhibits tumor growth in vivo and in vitro and could be used for the treatment of cancer, either alone or in combination with other treatments [10, 19].

Table 1: Nutritional Supplement (NL-Proximate) Analysis of Saffron.

\begin{tabular}{ll}
\hline Analysis & $\begin{array}{l}\text { Results } \\
\text { (per 1oo g serving size) }\end{array}$ \\
\hline Moisture & $7.7 \mathrm{~g}$ \\
Ash & $4.6 \mathrm{~g}$ \\
Protein & $15.6 \mathrm{~g}$ \\
Fat & $5.5 \mathrm{~g}$ \\
Total Carbohydrates & $69.6 \mathrm{~g}$ \\
Calories & $363 \mathrm{cal}$ \\
Calories from Fat & $22.1 \mathrm{cal}$ \\
\hline
\end{tabular}

Table 2: Nutritional Vitamins and minerals of Saffron

\begin{tabular}{ll}
\hline Vitamins & $<100 \mathrm{IU}$ \\
\hline Vitamin A & $<1.0 \mathrm{mg}$ \\
Vitamin C & $800 \mu \mathrm{g}$ \\
Folic Acid & - \\
Minerals & $124 \mathrm{mg}$ \\
Calcium & $0.908 \mathrm{mg}$ \\
Copper & $23.7 \mathrm{mg}$ \\
Iron & $154 \mathrm{mg}$ \\
Magnesium & $2.44 \mathrm{mg}$ \\
Manganese & $404 \mathrm{mg}$ \\
Phosphorus & $1750 \mathrm{mg}$ \\
Potassium & $39.0 \mathrm{mg}$ \\
Sodium & $4.15 \mathrm{mg}$ \\
Zinc &
\end{tabular}

Table 3: Nutritional Fatty acids of Saffron

\begin{tabular}{ll}
\hline Analysis & $\begin{array}{l}\text { Results (per 1oo g serving } \\
\text { size) }\end{array}$ \\
\hline 8:0 Caprylic & $<0.003 \mathrm{~g}$ \\
10:0 Capric & $<0.003 \mathrm{~g}$ \\
12:0 Lauric & $0.011 \mathrm{~g}$ \\
14:0 Myristic & $0.012 \mathrm{~g}$ \\
14:1 Myristoleic & $<0.003 \mathrm{~g}$ \\
15:0 Pentadecanoic & $0.003 \mathrm{~g}$ \\
15:1 Pentadecenoic & $<0.003 \mathrm{~g}$ \\
16:0 Palmitic & $0.425 \mathrm{~g}$ \\
16:1 Palmitoleic & $0.008 \mathrm{~g}$ \\
17:0 Heptadecanoic & $0.006 \mathrm{~g}$ \\
17:1 Heptadecenoic & $<0.003 \mathrm{~g}$ \\
18:0 Stearic & $0.030 \mathrm{~g}$ \\
18:1 Oleic & $0.314 \mathrm{~g}$ \\
18:2 Linoleic & $1.20 \mathrm{~g}$ \\
18:3 Gamma Linolenic & $<0.003 \mathrm{~g}$ \\
18:3 Linolenic & $0.394 \mathrm{~g}$ \\
20:0 Arachidic & $<0.003 \mathrm{~g}$ \\
20:1 Eicosenoic & $0.012 \mathrm{~g}$ \\
20:2 Eicosadienoic & $0.036 \mathrm{~g}$ \\
20:3 Eicosatrienoic & $<0.003 \mathrm{~g}$ \\
20:4 Arachidonic & $<0.003 \mathrm{~g}$ \\
22:0 Behenic & $0.008 \mathrm{~g}$ \\
Saturated Fat & $0.471 \mathrm{~g}$ \\
Monounsaturated Fat & $0.321 \mathrm{~g}$ \\
Polyunsaturated Fat & $1.56 \mathrm{~g}$ \\
Sum of Fatty Acids & $2.46 \mathrm{~g}$ \\
\hline & \\
\hline & \\
\hline
\end{tabular}




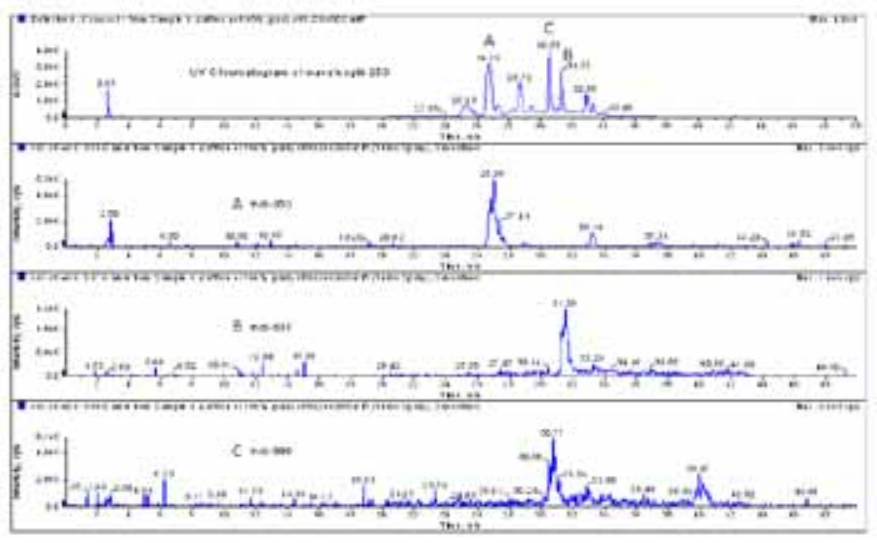

Figure 1: Chromatogram of the Crocus sativus L. sample analyzed by ultraviolet at $250 \mathrm{~nm}$.

\section{DISCUSSION}

Saffron is a very valuable spice with many traditional medicinal usages. The high amount of carotenoids in saffron including crocin, crocetin and dimethyl-crocetin are responsible for some biological functions of saffron. Most of the studies on the effect of saffron, indicates the significant inhibitory effects of the Crocus sativus components on the synthesis of nucleic acids in different human cancer cell lines [24].

As the studies have shown, diets rich in antioxidants will lower the risk of several chronic diseases and protect the body against the development and growth of tumor cells. Therefore, saffron and its constituents with their antioxidant properties can act as a protecting agent for the prevention of some serious diseases like cancer [25].

Crocus sativus L. extract used in several studies were prepared from stigmas of Crocus sativus. It contains several pharmacologically active constituents. Saffron has antioxidant properties; these have been showed in humans, where saffron (50 mg, twice a day) decreases the lipoprotein oxidation susceptibility [20]. Also crude methanol extract of saffron and its compound crocin have been exhibited high antioxidant and scavenging properties [21].

The oral administration of the saffron ethanolic extract (200 $\mathrm{mg} / \mathrm{kg}$ body $\mathrm{wt}$ ) increased the life span of Swiss albino mice intraperitoneally transplanted with sarcoma-18o (S-180) cells, Ehrlich ascites carcinoma (EAC) or Dalton's lymphoma ascites (DLA) tumors [22], and it has an inhibitory effect on chemical carcinogenesis in mice using two stage assay system [16].

Crocetin protects body against free radicals and the studies have shown its role as an antitumor agent [15]

The effect of crocetin on two different types of animal tumors, skin papillomas and Rous sarcoma have been studied and shown that crocetin decreased the number of tumor cells and delayed the onset of the tumors as well [23]. A recent study showed that crocetin (20 $\mathrm{mg} / \mathrm{kg}$ ) reverted the level of lipid peroxidation induced by Benzo (a) pyrene(B(a)P), also increased the activities of the enzymic antioxidants and glutathione metabolizing enzymes. Showing that crocetin is a scavenger of free radicals and a potent antitumor agent [15].

Crocin inhibits the growth of HeLa cells and suggested apoptosis induction and showed important inhibitory effects on skin-tumor initiation and promotion induced by 7 , 12-dimethylbenz[a]anthracene (DMBA) and 12-0-tetradecanoylphorbol-13-acetate (TPA), respectively [18].

Many studies during the last decade, demonstrated the inhibitory effect of saffron and its components in vitro, on several cancer types such as carcinoma, leukemia, prostate, pancreatic, and several other tumor cells [26].

SAFETY: The toxicity of saffron has been studied by many researchers and the levels of toxicity found to be very low. The studies showed that the concentration of o to $5 \mathrm{~g} / \mathrm{kg}$ was non-toxic to mice [7].

Also hematological and biochemical studies on the toxicity of saffron extract indicates that there are no severe toxicological sign found in kidney, liver or bladder within the normal range of use [22].

\section{CONCLUSION}

In summary, our study suggests that crocin and crocetin found in Crocus sativus L. may be efficacious in treating several or certain type of cancer. Considering the popularity of locally used chemical drugs in cancer patients, Crocus sativus L. should be investigated further as a natural viable option in the treatment of prostate, pancreatic, or other types of cancer.

$* * * * * * * * *$

\section{Author Contributions}

Rafie Hamidpour - Conception and design, Analysis and interpretation of data, Critical revision of the article, Final approval of the version to be published

Soheila Hamidpour - Analysis and interpretation of data, Critical revision of the article, Final approval of the version to be published

Mohsen Hamidpour - Analysis and interpretation of data, Critical revision of the article, Final approval of the version to be published

Mina Shahlari - Conception and design, Critical revision of the article, Final approval of the version to be published

\section{Guarantor}

The corresponding author is the guarantor of submission.

\section{Conflict of Interest}

Authors declare no conflict of interest.

\section{Copyright}

(C) Rafie Hamidpour et al. 2013; This article is distributed under the terms of Creative Commons attribution 3.0 License which permits unrestricted use, distribution and 
reproduction in any means provided the original authors and original publisher are properly credited. (Please see www.ijcasereportsandimages.com/copyright-policy.php for more information.)

\section{REFERENCES}

1. Peter K. V. Saffron. Handbook of Herbs and Spices. CRC Press 2000;Boca Raton:276-286.

2. Caballero-Ortega H, Pereda-Miranda R, Abdullaev FI. HPLC Quantification of Major Active Components from 11 Different Saffron (Crocus sativus L.) Sources. Food Chemistry 2007;100:1126-31.

3. Sánchez AM, Carmona M, Zalacain A, Carot JM, Jabaloyes JM, Alonso GL. Rapid Determination of Crocetin Esters and Picrocrocin from Saffron Spice (Crocus sativus L.) Using UV-Visible Spectrophotometry for Quality Control. J Agric Food Chem 2008 May 14;56(9):3167-5.

4. Aung HH, Wang CZ, Ni M, et al. Crocin from Crocus sativus Processes Significant Anti-proliferation Effects on Human Colorectal Cancer Cells. Exp Oncol 2007 Sep;29(3):175-80.

5. Li N, Lin G, Kwan YW, Min ZD. Simultaneous Quantification of Five Major Biologically Active Ingredients of Saffron by High-performance Liquid Chromatography. J Chromatogr A 1999 Jul 23;849(2):349-55.

6. Tarantilis PA, Polissiou M, Manfait M. Separation of Picrocrocin, Cis-trans-crocins and Safranal of Saffron Using High-performance Liquid Chromatography with Photodiode-array Detection. J Chromatogr A 1994 Mar 25;664(1):55-61.

7. Chryssanthi DG, Lamari FN, Iatrou G, Pylara A, Karamanos NK, Cordopatis P. Inhibition of Breast Cancer Cell Proliferation by Style Constituents of Different Crocus Species. Anticancer Res 2007 JanFeb;27(1A):357-62.

8. Kanakis CD, Tarantilis PA, Tajmir-Riahi HA, Polissiou MG. Interaction of tRNA with Safranal, Crocetin, and Dimethylcrocetin. J Biomolecular Structure \& Dynamics 2007 Jun;24(6):537-46.

9. Kanakis CD, Tarantilis PA, Tajmir-Riahi HA, Polissiou MG. DNA Interaction with Saffron's Secondary Metabolites Safranal, Crocetin, and Dimethylcrocetin. DNA Cell Biol 2007 Jan;26(1):63-70.

10. Hosseinzadeh H, Sadeghnia HR. Effect of Safranal, A Constituent of Crocus sativus (Saffron), on Methyl Methanesulfonate (MMS)-Induced DNA Damage in Mouse Organs: An Alkaline Single-Cell Gel Electrophoresis (Comet) Assay. DNA Cell Biol 2007 Dec;26(12):841-6.

11. Abdullaev FI. Cancer chemopreventive and tumoricidal properties of saffron (Crocus sativus L.). Exp Biol Med 2002;227(1):20-5.

12. Abdullaev FI, Espinosa-Aguirre JJ. Biomedical Properties of Saffron and its Potential Use in Cancer Therapy and Chemoprevention Trials. Cancer Detect Prev 2004;28(6):426-32.

13. Abdullaev FI, Frenkel GD. The Effect of Saffron on Intracellular DNA, RNA and Protein Synthesis in Malignant and Non-malignant Human Cells. Biofactors 1992 Dec;4(1):43-5.
14. Surh Y, Na H, Lee HJ. Chemopreventive Effects of Selected Spice Ingredients. Phytopharmaceuticals in Cancer Chemoprevention 2005:575-98.

15. Magesh V, Singh JP, Selvendiran K, Ekambaram G, Sakthisekaran D. Antitumour Activity of Crocetin in Accordance to Tumor Incidence, Antioxidant Status, Drug Metabolizing Enzymes and Histopathological Studies. Molecular and Cellular Biochemistry 2006 Jul;287(1-2):127-35.

16. Salomi MJ, Nair SC, Panikkar KR. Inhibitory Effects of Nigella sativa and Saffron (Crocus sativus) on Chemical Carcinogenesis in Mice. Nutr Cancer 1991;16(1):67-2.

17. Konoshima T, Takasaki M, Tokuda H, et al. Crocin and Crocetin Derivatives Inhibit Skin Tumour Promotion in Mice. Phytotherapy Research 1998;12:400-4.

18. Escribano J, Alonso GL, Coca-Prados M, Fernandez JA. Crocin, Safranal and Picrocrocin from Saffron (Crocus sativus L.) Inhibit the Growth of Human Cancer Cells in Vitro. Cancer Lett 1996 Feb 27;100(12):23-30.

19. Schmidt M, Betti G, Hensel A. Saffron in Phytotherapy: Pharmacology and Clinical Uses. Wien Med Wochenschr 2007;157(13-14):315-9.

20. Verma SK, Bordia A. Antioxidant Property of Saffron in Man. Indian J Med Sci 1998 May;52(5):205-7.

21. Assimopoulou AN, Sinakos Z, Papageorgiou VP. Radical Scavenging Activity of Crocus Sativus L. Extract and Its Bioactive Constituents. Phytother Res 2005 Nov;19(11):997-1000.

22. Nair SC, Pannikar B, Panikkar KR. Antitumour Activity of Saffron (Crocus sativus). Cancer Lett 1991 May 1;57(2):109-4.

23. Gainer JL, Wallis DA, Jones JR. The effect of crocetin on skin papillomas and Rous sarcoma. Oncology 1976;33(5-6):222-4.

24. Ashrafi M, Bathaie SZ, Taghikhani M, MoosaviMovahedi AA. The effect of carotenoids obtained from saffron on histone $\mathrm{H} 1$ structure and $\mathrm{H} 1-$ DNA interaction. Int $\mathrm{J}$ Biol Macromol 2005 Sep 15;36(4):246-52.

25. Premkumar K, Thirunavukkarasu C, Abraham SK, Santhiya ST, Ramesh A. Protective Effect of Saffron (Crocus sativus L.) Aqueous Extract Against Genetic Damage Induced by Anti-tumor Agents in Mice. Human \& Experimental Toxicology Journal 2006 Feb;25(2):79-84.

26. Abdullaev Jafarova F, Caballero-Ortega $\mathrm{H}$, Riverón-Negrete L, et al. In vitro evaluation of the chemopreventive potential of saffron. Rev Invest Clin 2002 Sep-Oct;54(5):430-6. 
Access PDF of article on other devices other devices

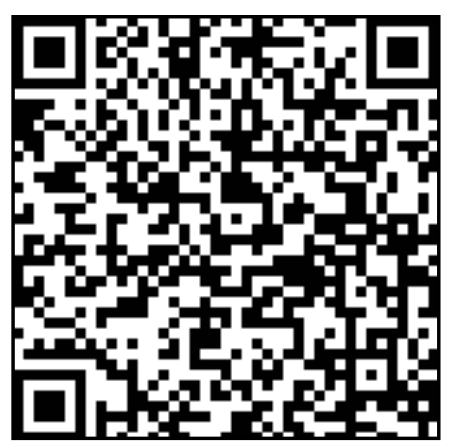

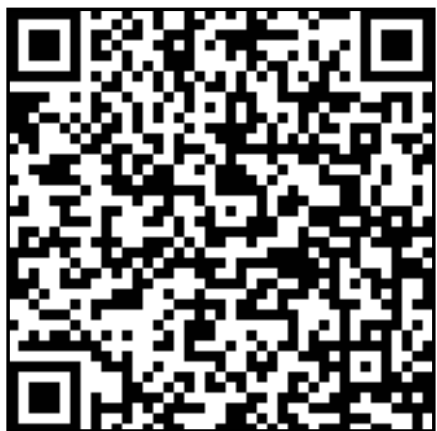

